American Journal of Environmental Sciences 8 (3): 291-296, 2012

ISSN 1553-345X

(C) 2012 Science Publications

\title{
Preliminary Evaluation of the Potential Biogas Production of Food-Processing Industrial Wastes
}

\author{
C. Roati, S. Fiore, B. Ruffino, \\ F. Marchese, D. Novarino and M.C. Zanetti \\ Department of Land, Environment and Infrastructures Engineering, \\ DIATI-Politecnico di Torino, Corso Duca degli Abruzzi 24, 10129 Torino, Italy
}

\begin{abstract}
Problem statement: An Anaerobic Digestion (AD) process, traditionally applied to wastewater and sewage sludge treatment, has a great potential in the valorization of foodprocessing industry wastes. Approach: This study is focused on the evaluation of the theoretical biogas and methane production of some food wastes, coming out from rice, hazelnut and wine processing, on the grounds of their physical-chemical characterization. Results: Almost all of the considered samples exhibited biogas theoretical yields equal to about $0.7-1.6 \mathrm{~m}^{3} / \mathrm{kg}_{\mathrm{vs}}$ and methane contents equal to about $40-60 \%$ v/v. Conclusion: Although the undeniable limitations of a theoretical evaluation, the gathered results may be useful in planning future experimental tests.
\end{abstract}

Key words: Food wastes, biomass, anaerobic digestion, biogas production

\section{INTRODUCTION}

Anaerobic Digestion (AD) of biomass is a wellknown natural process of biodegradation of organic matter performed by specific microorganisms that transform a biodegradable substrate in biogas and produce a stabilized solid residue defined digestate. The general anaerobic transformation can be described by the Eq. 1 (Tchobanoglous et al., 1993):

Organic matter $+\mathrm{H}_{2} \mathrm{O}+$ nutrients $\rightarrow$

new cells + resistant organic matter +

$+\mathrm{CO}_{2}+\mathrm{CH}_{4}+\mathrm{NH}_{3}+\mathrm{H}_{2} \mathrm{~S}+$ heat

Biogas is made of carbon dioxide, methane, ammonia, hydrogen sulfide, water vapor and other minor components, whose volumetric distribution depends on the substrate characteristics and on the process operating conditions. The biogas production may be artificially enhanced controlling the occurring biochemical reactions in order to maximize the methane production and consequently the energy recovery from the digested biomass.

$\mathrm{AD}$ has had both civil and industrial applications around the world as a technology for the treatment of organic wastes and the generation of energy. The digestion of sewage sludge (Vismara, 1988) in municipal wastewater treatment plants and of manure (Labatut et al., 2011) in farms represent the most consolidated technologies, while AD application to agricultural and industrial by-products like crops (Kalra and Panwar, 1986; Dinuccio et al., 2009), Organic Fraction Of Municipal Solid Wastes (OFMSW) (Davidsson et al., 2007; Gunaseela, 1997), food-processing wastes (Labatut et al., 2011;
Dinuccio et al., 2009; Gunaseela, 1997; Moletta, 2005) and wastewater (Fountoulakis et al., 2008; MayaAltamira et al., 2008) has been experimented more recently, usually in co-digestion processes (Labatut et al., 2011; Alvarez and Liden, 2008; Bouallagui et al., 2009), both on laboratory and real scale.

A summary of typical biogas yields resulting from the anaerobic digestion of the above cited matrices is reported in Table 1.

In particular, the possibility to biodegrade anaerobically food-processing industry wastes represents an interesting solution for multiple reasons:

- Actual European regulations (EU Directive 1999/31/CE and Decision 2003/33/CE) banned putrescible waste landfilling;

- Energy recovery from wastes represents an economic and environmental advantage;

- Together with other ecological choices, energy recovery from wastes helps to improve producer's image in front of consumers and to enter the Green economy market;

However, since literature data about the AD of food-processing industry wastes are limited, it appears useful to estimate the theoretical biogas and methane production in order to evaluate the technical and economic feasibility of the process, in prevision of successive laboratory-scale and pilot-scale digestion tests.

The aim of the present study is the preliminary calculation of the theoretical biogas and methane production, on the grounds of a physical-chemical characterization, applied to some waste coming from food-processing industries typical of Piedmont, a region in the north-west of Italy (Fig. 1). 
Table 1: Biomasses and organic wastes usable as feedstock in AD: biogas yields for categories (in bold) (Piccinini, 2005) and methane yields referred to single wastes

\begin{tabular}{|c|c|c|}
\hline Substrate & Yield & References \\
\hline Manure (pigs, cattle, poultry and rabbits) & $0.2-0.5 \mathrm{~m}^{3}{ }_{\text {biogas }} / \mathrm{kg}_{\mathrm{vs}}$ & \\
\hline Dairy manure & $0.2 \mathrm{~m}^{3} \mathrm{CH}_{4} / \mathrm{kg}_{\mathrm{VS}}$ & Labatut et al. (2011) \\
\hline Manure separated liquid & $0.3 \mathrm{~m}_{\mathrm{CH} 4}^{3} / \mathrm{kg}_{\mathrm{VS}}$ & Labatut et al. (2011) \\
\hline Crops (straw, beet collars) & $0.35-0.4 \mathrm{~m}^{3}{ }_{\text {biogas }} / \mathrm{kg}_{\mathrm{vs}}$ & \\
\hline Rice bran & $0.1 \mathrm{~m}_{\text {biogas }}^{3} / \mathrm{kg}_{\mathrm{TS}}$ & Kalra and Panwar (1986) \\
\hline Rice straw & $0.2 \mathrm{~m}^{3} \mathrm{CH}_{4} / \mathrm{kg}_{\mathrm{VS}}$ & Dinuccio et al. (2009) \\
\hline Barley straw & $0.2 \mathrm{~m}_{\mathrm{CH} 4}^{3} / \mathrm{kg}_{\mathrm{vS}}$ & Dinuccio et al. (2009) \\
\hline $\begin{array}{l}\text { Organic wastes from food industry (whey, vegetable wastes, } \\
\text { yeasts and wastewater from distillery, brewery and winery) }\end{array}$ & $0.4-0.8 \mathrm{~m}^{3}{ }_{\text {biogas }} / \mathrm{kg}_{\mathrm{vs}}$ & \\
\hline Fruit and vegetables solid waste and wastewater & $0.2-0.4 \mathrm{~m}_{\mathrm{CH} 4}^{3} / \mathrm{kg}_{\mathrm{vs}}$ & $\begin{array}{l}\text { Gunaseela (1997) } \\
\text { Maya-Altamira et al. (2008) }\end{array}$ \\
\hline Milk whey & $0.5 \mathrm{~m}_{\mathrm{CH}}^{3} / \mathrm{kg}_{\mathrm{VS}}$ & Dinuccio et al. (2009) \\
\hline Grape stalk & $0.1 \mathrm{~m}_{\mathrm{CH} 4}^{3} / \mathrm{kg}_{\mathrm{Vs}}$ & Dinuccio et al. (2009) \\
\hline Pomace & $0.1 \mathrm{~m}_{\mathrm{CH} 4}^{3} / \mathrm{kg}_{\mathrm{VS}}$ & $\begin{array}{l}\text { Dinuccio et al. }(2009) \\
\text { Failla and Restuccia (2009) }\end{array}$ \\
\hline Pomace & $0.4 \mathrm{~m}_{\mathrm{CH}}^{3} / \mathrm{kg}_{\mathrm{COD}}$ & Moletta (2005) \\
\hline Tomato skins and seeds & $0.2 \mathrm{~m}_{\mathrm{CH} 4}^{3} / \mathrm{kg}_{\mathrm{VS}}$ & Dinuccio et al. (2009) \\
\hline Olive mill wastewater & $0.1 \mathrm{~m}^{3} \mathrm{CH}_{4} / \mathrm{kg}_{\mathrm{COD}}$ & Fountoulakis et al. (2008) \\
\hline Winery residues extract & $0.1 \mathrm{~m}_{\mathrm{CH} 4}^{3} / \mathrm{kg}_{\mathrm{COD}}$ & Fountoulakis et al. (2008) \\
\hline Fish wastes & $0.3-0.4 \mathrm{~m}_{\mathrm{CH}}^{3} / \mathrm{kg}_{\mathrm{COD}}$ & Maya-Altamira et al. (2008) \\
\hline Plain pasta & $0.3 \mathrm{~m}_{\mathrm{CH} 4}^{3} / \mathrm{kg}_{\mathrm{VS}}$ & Labatut et al. (2011) \\
\hline Ice cream & $0.5 \mathrm{~m}^{3} \mathrm{CH} 4 \mathrm{~kg}_{\mathrm{VS}}$ & Labatut et al. (2011) \\
\hline Used vegetable oil & $0.6 \mathrm{~m}_{\mathrm{CH}}^{3} / \mathrm{kg}_{\mathrm{VS}}$ & Labatut et al. (2011) \\
\hline $\begin{array}{l}\text { Slaughterhouse wastes (fats, stomach and intestinal contents, } \\
\text { blood, flotation sludge) }\end{array}$ & $0.55-1 \mathrm{~m}^{3}$ biogas $/ \mathrm{kg}_{\mathrm{vs}}$ & \\
\hline Slaughterhouse wastewater & $0.3 \mathrm{~m}_{\mathrm{CH} 4}^{3} / \mathrm{kg}_{\mathrm{COD}}$ & $\begin{array}{l}\text { Fountoulakis et al. }(2008) \\
\text { Maya-Altamira } \text { et al. }(2008)\end{array}$ \\
\hline Sewage sludge & $0.25-0.35 \mathrm{~m}_{\text {biogas }}^{3} / \mathrm{kg}_{\mathrm{vS}}$ & \\
\hline Sewage sludge & $0.5 \mathrm{~m}_{\mathrm{CH} 4}^{3} / \mathrm{kg}_{\mathrm{VS}}$ & Vismara (1988) \\
\hline Organic fraction of municipal solid waste (OFMSW) & $0.4-0.6 \mathrm{~m}_{\text {biogas }}^{3} / \mathrm{kg}_{\mathrm{vs}}$ & \\
\hline Source sorted organic waste & $0.3-0.4 \mathrm{~m}^{3} \mathrm{CH}_{4} / \mathrm{kg}_{\mathrm{vs}}$ & Davidsson et al. (2007) \\
\hline Organic fraction of municipal solid waste & $0.1-0.4 \mathrm{~m}^{3} \mathrm{CH}_{3} / \mathrm{kg}_{\mathrm{VS}}$ & Davidsson et al. (2007) \\
\hline Energetic crops (corn, sorghum) & $0.55-0.75 \mathrm{~m}_{\text {biogas }}^{3} / \mathrm{kg}_{\mathrm{vS}}$ & \\
\hline Maize drying up residues & $0.3 \mathrm{~m}_{\mathrm{CH} 4}^{3} / \mathrm{kg}_{\mathrm{VS}}$ & Dinuccio et al. (2009) \\
\hline
\end{tabular}

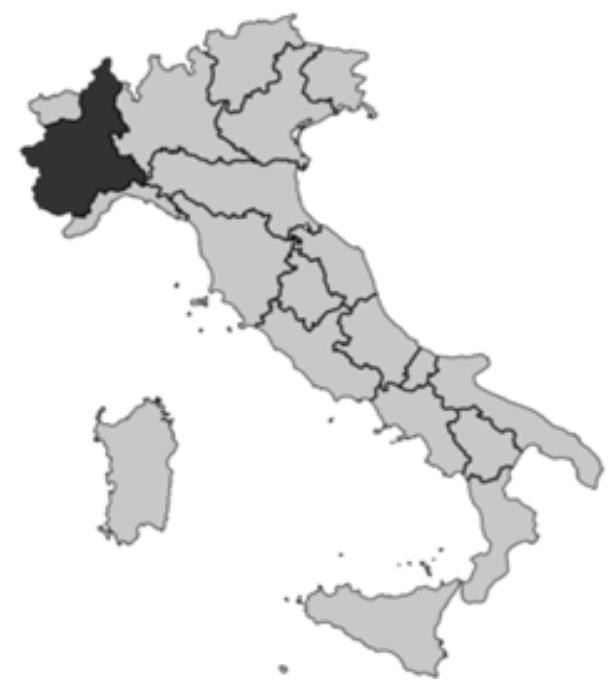

Fig. 1: localization of Piedmont region in Italy

Moreover, the results are discussed, in order to identify the matrices with which the anaerobic process can be theoretically more efficient.

\section{MATERIALS AND METHODS}

Origin and state of samples: All the wastes considered in this study come from industries that produce or transform typical food products from Piedmont region: hazelnuts, wine and rice (Table 2).
Except for wine lees, all the samples are solid byproducts, some of which appear as a powder (RHS, FHS, LHS and RB).

Pre-treatments: Before the characterization, the sample Rice Hull (RH) was grinded in an eccentric masses mill, while the sample Pomace (P) was chopped and then manually grinded.

pH measurement: The $\mathrm{pH}$ measurement was performed by means of an Orion 420A pH-meter equipped with a glass $\mathrm{Ag} / \mathrm{AgCl}$ electrode, on the aqueous phase obtained from the contact of each sample with deionized water, with a solid/liquid ratio equal to $1: 10$.

Moisture determination: The moisture content (M) was determined in duplicate with a thermo-balance KERN MLS-N on pre-grinded and homogenized samples of about $5 \mathrm{~g}$ at $105^{\circ} \mathrm{C}$, until the loss of weight was less than $1 \mathrm{mg}$ in $240 \mathrm{sec}$.

Volatile solids determination: The Volatile Solids content (VS) was determined as the complement to 100 of the ashes, obtained as the residue after $1 \mathrm{~h}$ at $600^{\circ} \mathrm{C}$.

For both determinations ( $\mathrm{M}$ and VS) the standard methods EPA, were followed. 
Table 2: Description and state of the food-processing industry wastes samples

\begin{tabular}{|c|c|c|}
\hline Sample & Description & State \\
\hline RHS & Raw Hazelnut Skin ${ }^{a}$ & Solid \\
\hline FHS & Fine Hazelnut Skin ${ }^{\mathrm{b}}$ & Solid \\
\hline LHS & Large Hazelnut Skin ${ }^{c}$ & Solid \\
\hline WL & Wine Lees & Dense liquid \\
\hline $\mathrm{P}$ & grape Pomace & Solid \\
\hline RH & Rice Hull & Solid \\
\hline $\mathrm{RB}$ & Rice Bran & Solid \\
\hline
\end{tabular}

Elemental analysis: The elemental composition of samples was investigated: carbon, nitrogen, hydrogen and sulfur contents were determined using a CHNS-O Thermo Fisher Flash 2000 Elemental Analyzer EA 1112. The oxygen content was assumed as the complementary fraction.

Calculation of the theoretical biogas $\left(B_{\text {th }}\right)$ and methane $\left(\mathbf{M}_{\mathrm{th}}\right)$ yield: The first step of the present study was the characterization of the considered wastes in order to obtain their composition. In fact, the maximum theoretical biogas production and the amount of methane fraction may be foreseen on the grounds of the organic matter elemental composition. Buswell and Neave proposed an equation (Tchobanoglous et al., 1993; Buswell and Neave, 1930) derived from the stoichiometries balance between the quantity of organic matter (expressed by the formula $\mathrm{C}_{\mathrm{a}} \mathrm{H}_{\mathrm{b}} \mathrm{O}_{\mathrm{c}} \mathrm{N}_{\mathrm{d}}$ ) to be biodegraded and the gaseous products resulting from its anaerobic biodegradation:

$$
\begin{aligned}
& \mathrm{C}_{\mathrm{a}} \mathrm{H}_{\mathrm{b}} \mathrm{O}_{\mathrm{c}} \mathrm{N}_{\mathrm{d}}+\left(\mathrm{a}-\frac{\mathrm{b}}{4}-\frac{\mathrm{c}}{2}+\frac{3 \mathrm{~d}}{4}\right) * \mathrm{H}_{2} \mathrm{O} \rightarrow \\
& \left(\frac{4 \mathrm{a}+\mathrm{b}-2 \mathrm{c}-3 \mathrm{~d}}{8}\right) * \mathrm{CH}_{4}+\left(\frac{4 \mathrm{a}-\mathrm{b}+2 \mathrm{c}+3 \mathrm{~d}}{8}\right) \\
& * \mathrm{CO}_{2}+\mathrm{d} * \mathrm{NH}_{3}
\end{aligned}
$$

Equation 2 describes the complete degradation of all the carbon present in the substrate, considering also the fraction of organic matter that commonly is not transformed, that is the carbon necessary to the microorganism metabolism $(5-10 \%$ of the inlet carbon), the portion slowly degradable (lignin, cellulose) that has not enough time to be digested and the not biodegradable fraction. Moreover, it is assumed that the biogas is simply a binary mix of methane and carbon dioxide.

This general balance and in particular its expression as the maximum theoretical biogas (3) and methane (4) specific production was applied to the considered samples (Eq. 3 and 4):

$\mathrm{B}_{\mathrm{th}}\left[\frac{\mathrm{m}^{3}}{\mathrm{~kg}_{\mathrm{vs}}}\right]=\frac{\mathrm{a} * 22.415}{12 \mathrm{a}+\mathrm{b}+16 \mathrm{c}+14 \mathrm{~d}}$

$\mathrm{M}_{\mathrm{th}}\left[\frac{\mathrm{m}^{3}}{\mathrm{~kg}_{\mathrm{vs}}}\right]=\frac{\left(\frac{4 \mathrm{a}+\mathrm{b}-2 \mathrm{c}-3 \mathrm{~d}}{8}\right) * 22.415}{12 \mathrm{a}+\mathrm{b}+16 \mathrm{c}+14 \mathrm{~d}}$
The so calculated results, considering the above cited limitations, are obviously higher than every gas yield found in real or pilot plant applications, as well because of the strong dependence of the anaerobic process on several parameters, mainly operative, other than the atomic composition of the substrate. Nevertheless, Buswell and Neave equation represents a useful tool to select promising substrates in order to plan further laboratory and pilot scale tests, particularly if the calculation is referred only to the biodegradable fraction of the substrate. In this case, its reliability towards experimental laboratory results obtained from $\mathrm{AD}$ of food wastes has been proved (Labatut et al., 2011).

\section{RESULTS}

The results of the physical-chemical characterization of the studied samples are reported in Table 3.

Moisture content, $\mathrm{pH}$ value, $\mathrm{C} / \mathrm{N}$ ratio and Volatile Solids (VS) content are the most important parameters to consider in planning an AD process. Typical values of these parameters commonly reported for a correct anaerobic digestion are $\mathrm{pH}$ values between 6.5 and 7.5 (APAT, 2005) and a C/N ratio between 25 and 30 (Pind et al., 2003), while the moisture content influences the choice of digester's technology (wet, semi-wet or dry). Finally, the VS amount gives an idea of the organic substance content easily available in the AD process.

The three groups of by-products employed, residues coming from the industrial processing of hazelnut, grapes and rice, appeared homogeneous in their own categories regarding the $\mathrm{pH}$ value and the moisture content.

The elemental analysis confirmed that the matrices are very rich in carbon, which represents around the $50 \%$ of the whole weight for hazelnut residues and a little less for rice by-products. Wine lees and pomace present smaller carbon content, because of the high moisture value that increases the total weight of the material.

Due to the pure organic nature of the treated waste, a very high content in VS is common to all samples.

Table 3: Results of the physical-chemical characterization of the studied samples

$$
\text { Elemental analysis }{ }^{\mathrm{b}}
$$

\begin{tabular}{lrrlrrlll} 
Sample & $\mathrm{pH}$ & \multicolumn{1}{c}{$\mathrm{M}^{\mathrm{a}}$} & $\mathrm{N}$ & \multicolumn{1}{c}{$\mathrm{C}$} & \multicolumn{1}{c}{$\mathrm{H}$} & $\mathrm{S}$ & $\mathrm{C} / \mathrm{N}$ & $\mathrm{VS}^{\mathrm{c}}$ \\
\hline RHS & 5.7 & 10.9 & 1.1 & 45.7 & 5.4 & 0.0 & 42 & 94.4 \\
FHS & 5.2 & 4.5 & 1.2 & 56.8 & 6.8 & 0.1 & 49 & 96.3 \\
LHS & 5.5 & 6.0 & 2.2 & 54.6 & 7.2 & 0.1 & 25 & 97.2 \\
WL & 3.8 & 92.2 & 0.2 & 7.4 & 10.4 & 0.0 & 34 & 90.4 \\
P & 3.6 & 48.1 & 0.8 & 22.1 & 8.6 & 0.0 & 28 & 90.0 \\
RH & 7.2 & 9.4 & 0.5 & 38.5 & 5.1 & 0.0 & 86 & 83.4 \\
RB & 6.9 & 9.3 & 2.4 & 44.9 & 6.9 & 0.1 & 19 & 89.6
\end{tabular}

a percentage of moisture on Total Weight (TW), ${ }^{\mathrm{b}}$ percentage on TW, ${ }^{c}$ percentage of VS on DW 
Table 4: Calculation of the dry matter molecular formula and the theoretical biogas $\left(\mathrm{B}_{\mathrm{th}}\right)$ and methane $\left(\mathrm{M}_{\mathrm{th}}\right)$ yield of each sample

\begin{tabular}{|c|c|c|c|c|c|c|c|c|c|c|c|c|c|}
\hline \multirow[b]{2}{*}{ Sample } & \multicolumn{4}{|c|}{ Elemental analysis ${ }^{\mathrm{a}}$} & \multicolumn{4}{|c|}{$\mathrm{C}, \mathrm{H}, \mathrm{O}, \mathrm{N}$ coefficients } & \multirow[b]{2}{*}{ Molecular formula } & \multirow[b]{2}{*}{$\mathrm{B}_{\text {th }}$} & \multirow[b]{2}{*}[\frac{\mathrm{m}^{3}}{\mathrm{kg}_{\mathrm{vs}}}]{} & \multirow[b]{2}{*}{$\mathrm{M}_{\mathrm{th}}$} & \multirow[b]{2}{*}[\frac{\mathrm{m}^{3}}{\mathrm{kg}_{\mathrm{vs}}}]{} \\
\hline & $\mathrm{N}$ & $\mathrm{C}$ & $\mathrm{H}^{\mathrm{b}}$ & $\mathrm{O}^{\mathrm{c}}$ & a & $\mathrm{b}$ & $\mathrm{c}$ & d & & & & & \\
\hline RHS & 1.1 & 45.7 & 5.4 & 47.8 & 49 & 53 & 31 & 1 & $\mathrm{C}_{49} \mathrm{H}_{53} \mathrm{O}_{31} \mathrm{~N}$ & & 0.96 & & 0.45 \\
\hline FHS & 1.2 & 56.8 & 6.8 & 35.2 & 57 & 76 & 24 & 1 & $\mathrm{C}_{57} \mathrm{H}_{76} \mathrm{O}_{24} \mathrm{~N}$ & & 1.11 & & 0.62 \\
\hline LHS & 2.2 & 54.6 & 7.2 & 36.1 & 29 & 42 & 12 & 1 & $\mathrm{C}_{29} \mathrm{H}_{42} \mathrm{O}_{12} \mathrm{~N}$ & & 1.08 & & 0.61 \\
\hline WL & 0.2 & 7.4 & 10.4 & 82.0 & 40 & 12 & 0 & 1 & $\mathrm{C}_{40} \mathrm{H}_{12} \mathrm{~N}$ & & 1.78 & & 0.94 \\
\hline $\mathrm{P}$ & 0.8 & 22.1 & 8.6 & 68.5 & 33 & 58 & 28 & 1 & $\mathrm{C}_{33} \mathrm{H}_{58} \mathrm{O}_{28} \mathrm{~N}$ & & 0.80 & & 0.39 \\
\hline RH & 0.5 & 38.5 & 5.1 & 56.0 & 100 & 125 & 93 & 1 & $\mathrm{C}_{100} \mathrm{H}_{125} \mathrm{O}_{93} \mathrm{~N}$ & & 0.79 & & 0.33 \\
\hline RB & 2.4 & 44.9 & 6.9 & 45.8 & 22 & 34 & 14 & 1 & $\mathrm{C}_{22} \mathrm{H}_{34} \mathrm{O}_{14} \mathrm{~N}$ & & 0.92 & & 0.48 \\
\hline
\end{tabular}

athe sulphur content was not considered because it is assumed negligible, ${ }^{b}$ the hydrogen content was purified from the portion held by the water molecules, ${ }^{c}$ the oxygen content was obtained as complement to 100 and purified from the portion held by the water molecules

The elemental analysis results allowed the estimation of the molecular formula that describes each sample. Since the substrates have all organic origins, we can postulate that their general chemical formula is $\mathrm{C}_{\mathrm{a}} \mathrm{H}_{\mathrm{b}} \mathrm{O}_{\mathrm{c}} \mathrm{N}_{\mathrm{d}} \mathrm{S}_{\mathrm{e}}$, depending on $\mathrm{C}, \mathrm{H}, \mathrm{O}, \mathrm{N}$ and $\mathrm{S}$ content defined by the employed instrument.

For practical reasons, the contribution of sulfur can be considered negligible in all the samples, since it represents around the $0.1 \% \mathrm{w} / \mathrm{w}$ of the sample (see Table 3). Oxygen content has been obtained by difference from the other components' percentages, assuming that the inorganic fraction could be ignored. The definition of the molecular formula is necessary for the application of the Buswell and Neave (1930) method to calculate the biogas production. For this reason, the hydrogen contribution was purified from the number of moles corresponding to the hydrogen present in the molecules of water (moisture) that, being a totally oxidized portion, don't take part to the anaerobic degradation and to the generation of biogas.

The coefficients a, b, c, d (Table 4) were obtained as the approximated ratio of each component number of moles to the minimum number of moles among all the components (in this case it is the nitrogen for every sample). Knowing the molecular formula it was possible to apply the Eq. 3 and 4 in order to evaluate the theoretical biogas $\left(\mathrm{B}_{\mathrm{th}}\right)$ and methane $\left(\mathrm{M}_{\mathrm{th}}\right)$ specific production of each sample (Table 4).

\section{DISCUSSION}

The results obtained from the characterization phase were compared with literature data reported in Table 1.

As far as wine residues are concerned, the comparison with two other Italian studies (Dinuccio et al., 2009; Failla and Restuccia, 2009) revealed a good correspondence for $\mathrm{pH}$ and VS content values of pomace, while some relevant differences were detected in the elemental composition results. In particular, the carbon content found in the present study results rather higher and a large range of values was found with respect to nitrogen content, perhaps because of the heterogeneity of the samples and the feature variability among different types of wines. Moreover, different detection methods were used: in fact, the cited studies found only the organic nitrogen and carbon contents, that might be lower that the total ones.

Rice hulls elemental composition results are in line with literature data ( $\mathrm{Lu}$ et al., 2008), while no complete characterization of hazelnut wastes was found in literature.

As predicted, the biogas theoretical yields $\left(\mathrm{B}_{\mathrm{th}}\right)$ obtained with the Buswell and Neave (1930) method and reported in Table 4, are optimistic with respect to the real experience of biogas production from food industry organic waste (Table 1), even if the range is about the same.

The reason of this discrepancy lies in the assumption made by Buswell and Neave that the volatile solids value can be approximated to the total solids one.

The consequence of this hypothesis is that the biogas and methane yields result overestimated and the error increases as the difference between TS and VS increases. For this reason, gas yields have been multiplied by the VS content (expressed by the VS/TS ratio), in order to obtain a more realistic datum (Table 5 and Fig. 2).

Considering the adjusted potentials, wine lees appears definitely the best substrate for anaerobic digestion among the ones studied (Fig. 2), with a $B_{a d}$ $=1.61 \mathrm{~m}_{\text {biogas }}^{3} / \mathrm{kg}_{\mathrm{TS}}$ and the highest methane potential among all samples $\left(0.85 \mathrm{~m}^{3}{ }_{\mathrm{CH} 4} / \mathrm{kg}_{\mathrm{TS}}\right)$.

Table 5: Biogas ( $\left.\mathrm{B}_{\mathrm{ad}}\right)$ and methane $\left(\mathrm{M}_{\mathrm{ad}}\right)$ yields adjusted taking into account the VS/TS ratio

\begin{tabular}{lcccc}
\hline Sample & VS/TS & $\mathrm{B}_{\mathrm{ad}}\left[\frac{\mathrm{m}^{3}}{\mathrm{~kg}_{\mathrm{TS}}}\right]$ & $\mathrm{M}_{\mathrm{ad}}\left[\frac{\mathrm{m}^{3}}{\mathrm{~kg}_{\mathrm{TS}}}\right]$ & $\frac{\mathrm{m}^{3} \mathrm{CH} 4}{\mathrm{~m}^{3} \text { biogas }}[\%]$ \\
\hline RHS & 94.4 & 0.91 & 0.43 & 47 \\
FHS & 96.3 & 1.07 & 0.60 & 56 \\
LHS & 97.2 & 1.05 & 0.59 & 56 \\
WL & 90.4 & 1.61 & 0.85 & 53 \\
P & 90.0 & 0.72 & 0.36 & 49 \\
RH & 83.4 & 0.66 & 0.28 & 42 \\
RB & 89.6 & 0.77 & 0.40 & 52 \\
\hline
\end{tabular}




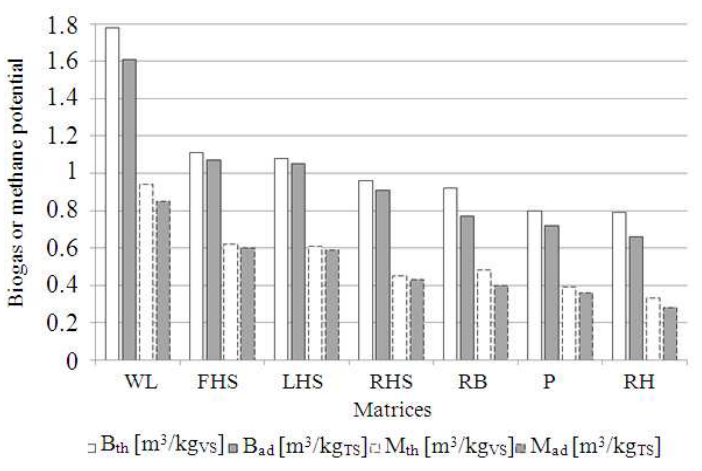

Fig. 2: Comparison between theoretical and adjusted potentials for each sample

This latter result is due to the absence of oxygen in the dry WL molecular formula: the oxygen contribution, in fact, represents a negative factor in the methane potential calculation.

Good performances were also found for pomace, for which a biogas potential of 0.72 $\mathrm{m}^{3}{ }_{\text {biogas }} / \mathrm{kg}_{\mathrm{TS}}$ was calculated.

The anaerobic digestion of winery and distillery residues and wastewater have been extensively investigated up to now: biogas yields from $\mathrm{AD}$ of pomace equal to $0.25 \mathrm{~m}_{\text {biogas }}^{3} / \mathrm{kg}_{\mathrm{vs}}$ with $46 \%$ of methane (Dinuccio et al., 2009), 0.12-0.16 $\mathrm{m}_{\text {biogas }}^{3} / \mathrm{kg}_{\mathrm{vs}}$ with $80 \%$ of methane (Failla and Restuccia, 2009) and 0.4-0.6 $\mathrm{m}_{\text {biogas }}^{3} / \mathrm{kg}_{\text {CoDremoved }}$ with $60-70 \%$ of methane (Moletta, 2005) have been obtained in different studies.

Literature data referred to wine and distillery residues (Table 1), compared to the theoretical values calculated in this study, suggest that a portion of the organic substance is not degraded in $\mathrm{AD}$ conditions. Dinuccio et al. (2009) suggest that this discrepancy is due to the high lignin content: the carbon in this form is very slowly biodegradable and cannot be easily gasified during the $\mathrm{AD}$ process.

As far as hazelnut waste is concerned, their biogas yields vary between 0.91 and $1.07 \mathrm{~m}^{3}$ biogas $/ \mathrm{kg}_{\mathrm{TS}}$ and FHS and LHS reached the highest methane/biogas ratio $(56 \%)$.

Looking for similar studies in literature, no experimentation of hazelnut waste as a substrate for AD could be found.

Rice residues resulted in a biogas potential equal to $0.66-0.77 \mathrm{~m}_{\text {biogas }}^{3} / \mathrm{kg}_{\mathrm{TS}}$, with a very low methane potential for $\mathrm{RH}\left(0.28 \mathrm{~m}_{\mathrm{CH} 4}^{3} / \mathrm{kg}_{\mathrm{TS}}\right)$ because of its high oxygen molecular content. This good biogas yield is quite in contrast with the experimentation performed by Kalra and Panwar (1986), who obtained a very low biogas production, from the $\mathrm{AD}$ of rice husk $\left(0.05 \mathrm{~m}_{\text {biogas }}^{3} / \mathrm{kg}_{\mathrm{TS}}\right.$ with $65 \%$ methane $)$. Again, the researchers stated that the high lignin content of the substrate was the reason. Moreover, the Kalra and
Panwar (1986) experimentation was performed at room temperature, without any digester heating and this factor contributes to decrease the gas yield.

\section{CONCLUSION}

Anaerobic digestion can be an interesting solution to treat organic residues and to obtain energy recovery from food-processing industry wastes and by-products. In this study hazelnut, wine and rice processing by-products were characterized and their theoretical biogas and methane yields were calculated using the Buswell and Neave (1930) formula.

The histogram in Fig. 2 shows the calculation results expressed as $\mathrm{m}^{3} / \mathrm{kg}_{\mathrm{vs}}$ with the assumption that volatile solids were equal to total solids and as $\mathrm{m}^{3} / \mathrm{kg}_{\mathrm{TS}}$ after the correction with the factor VS/TS.

It can be noticed that Wine Lees (WL) were identified as the best substrates among the ones considered, with a methane potential almost double with respect to the majority of the other samples $(0.85$ $\mathrm{m}^{3}{ }_{\mathrm{CH} 4} / \mathrm{kg}_{\mathrm{TS}}$ ).

The behavior of the other important winery residue, such as pomace $(\mathrm{P})$-appears less promising, nevertheless the values suggest that this kind of foodprocessing residues, because of their composition, constitute a good substrate for the methanogenic activity of bacteria.

Moreover, the three types of hazelnut skin (RHS, FHS and LHS) resulted in biogas potentials greater or equal to $0.9 \mathrm{~m}_{\text {biogas }}^{3} / \mathrm{kg}_{\text {TS }}$. Particularly, the fine (FHS) and large (LHS) hazelnut skins accomplished the highest methane percentage in the produced biogas. According to literature data, gas productions from the degradation of rice processing residues are the lowest among all matrices considered, especially as far as Rice Hull (RH) is concerned. However, the calculated yields suggest that also this kind of waste could be used in AD with success. It can be supposed that, with these substrates, the $\mathrm{AD}$ process is strongly influenced by factors that Buswell and Neave (1930) method does not consider, given the great difference in gas yields found in field tests.

In conclusion, the results are encouraging because they demonstrate the suitability of all the studied food-processing industry wastes to be treated in anaerobic conditions for biogas production. Nevertheless, the achieved data need to be validated performing laboratory and pilot tests that could take into account the following issues:

- Physical features of the substrates (temperature, $\mathrm{pH}$, moisture);

- VS/TS ratio in substrates;

- Carbon metabolized by microorganisms (biomass growth);

- Carbon non biodegradable (ashes);

- Carbon slowly degradable (cellulose, lignin...). 
Many studies (Fountoulakis et al., 2008; Alvarez, and Liden, 2008; Bouallagui et al., 2009; Panyue et al., 2008) stated that co-digesting different substrates improves the overall biogas yield. An interesting development of this study can be the experimentation of different mixtures of the food industry by-products themselves or together with other organic waste (manure, sewage sludge, crops...). This solution could be a way to balance parameters like substrate $\mathrm{C} / \mathrm{N}$ ratio or moisture in order to obtain the best substrate's conditions for the anaerobic digestion process and to improve the economical feasibility of this kind of treatment thanks to biogas production and specific gas yields.

\section{REFERENCES}

Tchobanoglous, G., H. Theisen and S.A. Vigil, 1993. Integrated Solid Waste Management: Engineering Principles and Management Issues. 2nd Edn., McGraw-Hill, ISBN-10: 0070632375 pp: 978.

Vismara, R., 1988. Depurazione Biologica: Teoria e processi. 2nd Edn., Hoepli, Milano Ulrico, ISBN-10: 8820316579, pp: 573.

Labatut, R.A., L.T. Angenent and N.R. Scott, 2011. Biochemical methane potential and biodegradability of complex organic substrates. Bioresource Technol., 102: 2255-2264. DOI: 10.1016/j.biortech.2010.10.035

Kalra, M.S. and J.S. Panwar, 1986. Anaerobic digestion of rice crop residues. Agric. Wastes, 17: 263-269. DOI: $10.1016 / 0141$ 4607(86)90134-4

Dinuccio, E., S. Menardo, F. Gioelli and P. Balsari, 2009. Valutazione della potenzialità produttiva, in termini di biogas, di alcune biomasse di origine agroindustriale.

Davidsson, A., C. Gruvberger, T.H. Christensen, T.L. Hansen and J.L.C. Jansen, 2007. Methane yield in source-sorted organic fraction of municipal solid waste. Waste Manag., 27: 406-414. DOI: 10.1016/j.wasman.2006.02.013

Gunaseela, V.N., 1997. Anaerobic digestion of biomass for methane production: A review. Biomass Bioenergy, 13: 83-114. DOI: 10.1016/S0961-9534(97)00020-2

Failla, S. and A. Restuccia, 2009. Impiego delle vinacce per scopi energetici: Prime valutazioni con un impianto da laboratorio.
Moletta, R., 2005. Winery and distillery wastewater treatment by anaerobic digestion. Water Sci. Technol. 51: 137-144. PMID: 15771109

Fountoulakis, M.S., S. Drakopoulou, S. Terzakis, E. Georgaki and T. Manios, 2008. Potential for methane production from typical Mediterranean agro-industrial by-products. Biomass and Bioenergy 32: 155-161. DOI: 10.1016/j.biombioe.2007.09.002

Maya-Altamira, L., A. Baun, I. Angelidaki and J.E. Schmidt, 2008. Influence of wastewater characteristics on methane potential in foodprocessing industry wastewaters. Water Res. 42: 2195-2203. PMID: 18191984

Alvarez, R. and G. Liden, 2008. Semi-continuous codigestion of solid slaughterhouse waste, manure and fruit and vegetable waste. Renewable Energy, 33: 726-734. DOI: 10.1016/j.renene.2007.05.001

Bouallagui, H., H. Lahdheb, E.B. Romdan, B. Rachdi and M. Hamdi, 2009. Improvement of fruit and vegetable waste anaerobic digestion performance and stability with co-substrates addition. J. Environ. Manag., 90: 1844-1849. DOI: 10.1016/j.jenvman.2008.12.002

Piccinini, S., 2005. Panoramica dei sistemi più diffusi di integrazione anaerobica/aerobica. "La digestione anaerobica e il compostaggio: l'integrazione operativa dei due sistemi", Milano.

Buswell, A.M. and S.L. Neave, 1930. Laboratory studies of sludge digestion. Department of Registration and Education.

Pind, P.F., I. Angelidaki, B.K. Ahring, K. Stamatelatou and G. Lyberatos, 2003. Monitoring and control of anaerobic reactors. Biomethanation II, 82: 135-182. DOI: 10.1007/3540-45838-7_4

Lu, Q., X.L. Yang and X.F. Zhu, 2008. Analysis on chemical and physical properties of bio-oil pyrolyzed from rice husk. J. Anal. Applied Pyrolysis, 82: 191-198. DOI: 10.1016/j.jaap.2008.03.003

Panyue, Z., G. Zeng, G. Zhang, Y. Li and B. Zhang et al., 2008. Anaerobic co-digestion of biosolids and organic fraction of municipal solid waste by sequencing batch process. Fuel Process. Technol., 89: 485-489. DOI: 10.1016/j.fuproc.2007.11.013 